\title{
Intermodal transportation perspectives in South Africa: a case study of its application within the Gauteng Province and lessons learned for other metropolitan areas
}

\author{
C. B. Schoeman \\ Research Unit for Environmental Sciences and Management, \\ North West University, South Africa
}

\begin{abstract}
Gauteng Province is located in the northern part of the South African national spatial system and is bordered by the Free State, North West, Limpopo and Mpumalanga Provinces. It is the smallest geographically of all the provinces, but the largest in terms of population and its contribution to the country's GDP. Originally, Gauteng Province developed on the wealth of gold ( $40 \%$ of the world's reserves). The economy has since diversified to more sophisticated sectors, such as finance, manufacturing, transport and telecommunications. It forms the economic engine of the Southern African region and the gateway to doing business in the rest of Africa. The study area is the smallest of the nine provinces, but contributes more than $30 \%$ to the national economy and $10 \%$ to the African economy.

Due to the locational factors the study area is currently fulfilling a primary role in the growth and development of the national economy and its spatial development. This also applies to development within the Africa continental spatial system. The Gauteng Provincial Government in 2013 published the Gauteng Integrated Transport Master Plan (GITMP). In this plan consideration is given to the promotion of intermodal transportation development.

The purpose of this paper is to assess the intermodal transport perspectives within the Gauteng Province and to relate it to the strategies as formulated in the National Development Plan (2012) for NATMAP 2050 for the national spatial system. The paper focuses on the use of specific planning and development
\end{abstract}


instruments to promote sustainable transportation planning and development. It's guiding giving influence and impacts on intra traffic movements through process linkages and alignment between strategy and implementation approaches are investigated. The findings will serve as a guideline to follow in application of similar strategy, planning and implementation approaches within other provincial spatial systems.

Keywords: modal integration, corridors, nodal development, spatial integration, strategy formulation.

\section{Introduction and points of departure}

The nature of spatial systems are becoming more complex due to the increase in urban densities and the resulting need to manage the interface between spatial development, transportation and environment from a sustainability perspective. The concept of 'sustainability' originated within the field of environmental sciences and is at present being 'introduced' in an ad hoc fashion within the spatial planning and transportation planning domains. This resulted in confusion on how 'sustainability' is being implied within the focus of transportation?

It is further complicated by the application of related terminology such as 'green orientated development' that sometimes represents nothing more than the application of technological advanced practices and more efficient and esthetical approaches in planning and development in general. Its differentiation from 'brown spaces' contributes further to complexities in developing of a common understanding of sustainable transportation and spatial planning practices and outcomes.

This 'disjointedness', however, is not related to the concept of sustainability only. Within a relative 'young' democracy such as South Africa, the dynamic and complex planning and development realities requires sometimes unconventional approaches in integrating ('sustainable') strategy formulation with operational ('implementation') practices. If the development of policy and legislation that impacts on planning and development since democratization in 1994, is taken into consideration, the nature of this 'disjointedness' or perceived lack of integration is clear. Such phenomenon inhibits delivery, economic growth and service delivery within some spheres of government and sectors of the economy that contradicts the sequential nature sustainable of spatial and transportation planning and development.

Of relevance in this regard is the National Spatial Planning Perspective (NSDP) [1] that dates back to 2006 whilst the National Development Plan (NDP) [2] containing detailed development strategies was only published in 2011/12. Similarly the National Transport Master Plan (NATMAP) [3] was completed in 2011. Abovementioned non-sequential rollout format contributes to complex and dynamic reality, within which intermodal transportation is to be planned, integrated, promoted and developed. 


\section{Purpose of the paper}

The purpose of this paper is to assess the development of intermodal transport perspectives within the Gauteng Province and to relate it to the strategies as formulated in the National Development Plan (2012) [2] and NATMAP 2050 [3] for the national spatial system. It focuses on the use of specific planning and development instruments to promote sustainable planning and development. Such principles may serve as a guideline to follow in application of similar strategy and implementation formulation within other spatial systems.

\section{Supporting theory and related concepts}

The theory and concepts related to the theme of this paper will be restricted to some selected components supporting the line of argument.

\subsection{Interface between transportation and spatial planning and development}

The basic building blocks of transportation consist of the movement of people, goods and services between points of origination and destination. This movement consists of transportation systems that influence the urban and rural characteristics and development of all spatial systems. It impacts on a community's character; the natural and human environment, as well as economic and spatial development patterns. For example, a transportation system can improve the economy, shape development patterns, and influence quality of life and the natural environment [4].

Transportation and spatial planning and development is integrated with functions such as land use, economic planning and development through, among others, the concepts of corridors, activity nodes, densification, land infill and transportation planning. It thus guides and shapes planning and development [5]. The interface with the environment is thus pivotal from a sustainability perspective.

\subsection{Intermodal and multimodal transportation}

An important concept that needs further clarification with regard to this paper is the use of the terminology of 'intermodal transportation' and 'multimodal transportation'. Pedersen [6] stated that multimodal transport implies transportation using several modes, but does not require any interoperability between modes. Intermodal transportation refers to the performing of a transportation task by interaction of various modes of transport inclusive of transfer between modes. For the purpose of this paper the concepts will be used interchangeably.

Litman [7] points out that multimodal (also called balanced or diverse) transport system, implies that consumers or users have various transportation options from which to choose (walking, cycling, ridesharing, public transit, telework, etc.) and incentives to use each for what it does best. According to 
Litman multimodal planning expands the scope of solutions that can be applied to transport problems. In terms of this statement the broader definition allows for integrated solutions to be considered, such as improvements to alternative modes, improved connections between modes, mobility substitutes such as telecommuting, and policies that increase land use accessibility to be considered in transportation network improvements [7].

\subsection{Strategic mobility management and integration}

Strategic planning according to Dressler [8] and Haberberg and Rieple [9] serves a variety of purposes in organizing attaining a vision, goals and objectives within an organization. Similar strategic and/or fundamental principles support transportation planning and spatial or regional planning [10] and [11]. The complexities involved in strategic transportation planning is best described in the term CLIOS (Complex, large-scale, integrated, open systems) [12].

Litman [7] points out that mobility management consists of various policies and programs that change travel behaviour in order to increase transport system efficiency. It includes various economic, social and environmental benefits. Conventional transportation evaluation practices tend to overlook and undervalue many of these benefits that are accrued by intermodal practices.

\subsection{Sustainability, planning and development}

When applied to the transportation sector, planning for sustainability can incorporate a variety of strategies with a view to conserve natural resources (including the use of clean fuels), to encourage modes other than single occupant vehicles, and to promote travel reduction strategies. Current trends in transportation planning and development contribute towards unsustainable conditions (such as including greenhouse gas emissions, energy insecurity, congestion, and various other ecological impacts) [13].

Although widespread uncertainty exists about how to address the goal and objective of a sustainable transportation system, transportation officials and stakeholders are now recognising that planning decisions have long-term implications and impacts. This implies focusing attention on how to prepare metropolitan and state-wide transportation plans and programs accordingly. Attaining a sustainable transportation system will require involvement by the public sector, private companies, and individual citizens [4, 14-16].

The core theory and points of departure above is fundamental in the development of intermodal transportation systems to address system wide deficiencies; accessibility; effectiveness; integration and sustainability. It emphasizes the need to integrate transportation; spatial and environmental planning and development [17].

\section{Location of the study area}

The study area consists of the Gauteng Province and is the smallest of the nine (9) provinces within the national spatial system of South Africa. The area is a 
major determinant and contributor of economic and social development in the Africa continental spatial system. Gauteng represents a microcosm of the South African national spatial system [18].

\section{National framework and instruments in promoting planning and development for intermodal transportation}

Intermodal transportation planning and development is guided by national frameworks and plans that direct macro level socio-economic, spatial, environmental and infrastructural development within the national spatial system. These national instruments should be considered before the approach towards intermodal transportation planning within the Gauteng Integrated Transportation Master Plan is addressed.

\subsection{National Development Plan (NDP) and Strategic Infrastructure Projects (SIPs)}

The NDP [2] aims to eliminate poverty and reduce inequality within the national spatial system by 2030 . South Africa can only realise these goals by drawing on the energies of its people, growing an inclusive economy, building capabilities, enhancing the capacity of the state, and promoting leadership and partnerships throughout society.

The NDP was preceded in 2011 with the National Planning Commission's Diagnostic Report [19] which sets out the achievements and shortcomings since democratization in 1994. It identifies the failure to implement policies and the absence of broad partnerships as the main reasons for slow progress. It sets out nine primary challenges. The NDP 2030 [2] provides a broad national strategic framework to guide key choices and actions. It identifies six interlinked development priorities as shown in Table 1.

Within the development vision, development goals and objectives for the national spatial system the central question relates to what should happen; where should it happen; when should it happen and how will it be managed within the provincial spatial systems as the operative places where spatial context should be given to the content of the national vision. The answer to this question, related to intermodal transport, is dealt with in the ITMP25 [21] and GEGDS [18].

The NDP 2030 [2] is supported by the South African National Infrastructure Plan (NIP) [20]. The NIP was formulated by the Presidential Infrastructure Coordinating Commission (PICC) in response to the NDP 2030. It includes 18 Strategic Integrated Projects (SIP's) that is geographically distributed within the national spatial system to support economic development within all provincial and local spatial systems (refer to Table 1). 
Table 1: Development and framework for interventions as included in the National Development Plan (NDP) and the National Infrastructure Plan (NIP) 2012.

\begin{tabular}{|c|c|c|}
\hline $\begin{array}{c}\text { Development reality to be } \\
\text { addressed }\end{array}$ & Development priorities & $\begin{array}{c}\text { Focus of } \\
\text { infrastructural } \\
\text { development }\end{array}$ \\
\hline $\begin{array}{l}\text { Too few people work. } \\
\text { The quality of school } \\
\text { education for black } \\
\text { people is poor. } \\
\text { - Infrastructure is poorly } \\
\text { located, inadequate and } \\
\text { under-maintained. } \\
\text { - Spatial divides hobble } \\
\text { inclusive development. } \\
\text { The economy is } \\
\text { unsustainably resource } \\
\text { intensive. } \\
\text { The public health system } \\
\text { cannot meet demand or } \\
\text { sustain quality. } \\
\text { Public services are } \\
\text { uneven and often of poor } \\
\text { quality. } \\
\text { Corruption levels are } \\
\text { high. } \\
\text { South Africa remains a } \\
\text { divided society. }\end{array}$ & $\begin{array}{l}\text { - Uniting all South } \\
\text { Africans around a } \\
\text { common programme to } \\
\text { achieve prosperity and } \\
\text { equity. } \\
\text { - Promoting active } \\
\text { citizenry to strengthen } \\
\text { development, democracy } \\
\text { and accountability. } \\
\text { - Bringing about faster } \\
\text { economic growth, higher } \\
\text { investment and greater } \\
\text { labour absorption. } \\
\text { - Focusing on key } \\
\text { capabilities of people and } \\
\text { the state. } \\
\text { - Building a capable and } \\
\text { developmental state. } \\
\text { - Encouraging strong } \\
\text { leadership throughout } \\
\text { society to work together } \\
\text { to solve problems. }\end{array}$ & 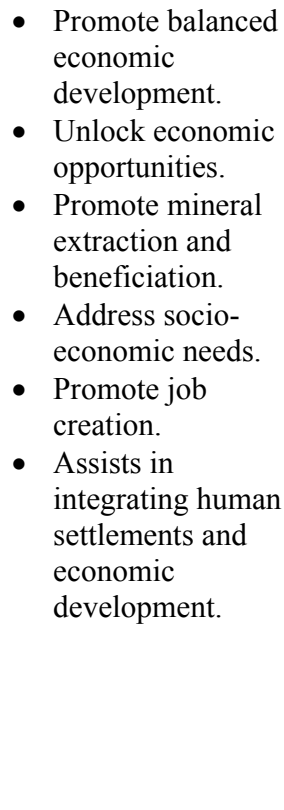 \\
\hline
\end{tabular}

Source: own construction from [2] and [20].

\subsection{National Transport Master Plan (NATMAP) 2050}

The NATMAP (2050) goal is to develop a dynamic; long term; and sustainable land use/multi-modal transportation systems framework for the development of network infrastructure facilities; interchange termini facilities and service delivery. The focus of NATMAP (2050) is to be demand responsive to national/provincial/district and/or any socio-economic growth strategy, and/or any sectoral integrated spatial development plan [3]. The application of strategic planning to transportation plans and problems are not a new phenomenon and/or development in long term spatial planning.

For the purposes of this paper the alignment and interface between the related planning instruments supporting intermodal transportation development as discussed above and the NATMAP Agenda for Action (Phase 4) [22] is of importance. Table 2 summarises the core considerations. 
Table 2: Core considerations included in NATMAP 2050 to promote intermodal transportation development.

\begin{tabular}{|c|c|}
\hline Focus & Intervention drivers \\
\hline 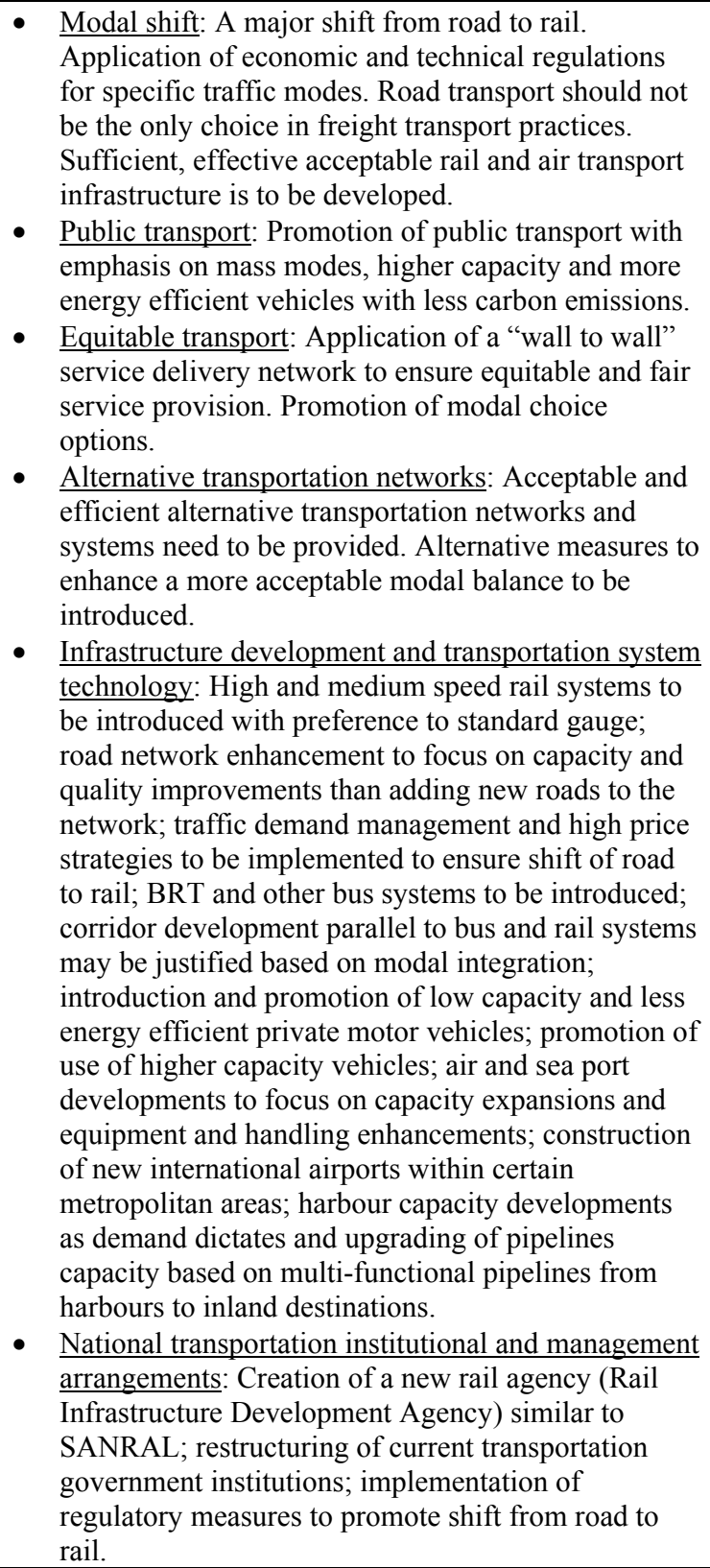 & $\begin{array}{l}\text { - Systematic economic } \\
\text { growth and } \\
\text { development. } \\
\text { - Normalization of the } \\
\text { RSA society and } \\
\text { political environment. } \\
\text { - Demographic } \\
\text { restructuring. } \\
\text { - Market preferences and } \\
\text { competitive } \\
\text { environment. } \\
\text { - Continuous spatial and } \\
\text { land use developments. } \\
\text { - Focussed and defined } \\
\text { corridor developments. } \\
\text { - Global energy and } \\
\text { environmental } \\
\text { challenges and } \\
\text { developments. } \\
\text { - Technological } \\
\text { innovations and } \\
\text { international best } \\
\text { practices. } \\
\text { - RSA's regional } \\
\text { connectivity. } \\
\text { - Systematic let-go of } \\
\text { discipline, reducing } \\
\text { standards and neglect of } \\
\text { responsibilities. } \\
\text { - Changing transportation } \\
\text { policy and governance } \\
\text { environment. }\end{array}$ \\
\hline
\end{tabular}

Source: own construction from [3, 22]. 


\section{Intermodal spatial and transportation planning development instruments within the Gauteng spatial system}

The planning and development instruments included in the Gauteng Integrated Transport Master Plan (First Draft) (GITMP) (2013) [21] consists of the components as shown in Table 3.

Table 3: Development and planning approach included in the Gauteng Integrated Transport Master Plan to promote intermodal transportation development.

\begin{tabular}{|c|c|c|}
\hline Developr & ent focus & Inter \\
\hline $\begin{array}{l}\text { The GITMP } \\
\text { describes the } \\
\text { current reality of } \\
\text { transport in the } \\
\text { Gauteng Global } \\
\text { City Region; how } \\
\text { it operates and the } \\
\text { framework within } \\
\text { which it operates. } \\
\text { How the Gauteng } \\
\text { Province expects } \\
\text { the population and } \\
\text { the economy to } \\
\text { grow in the next } \\
\text { 25 years and the } \\
\text { impacts this will } \\
\text { have on the } \\
\text { transport system. } \\
\text { What the } \\
\text { consequences may } \\
\text { be if the Province } \\
\text { continue doing } \\
\text { things the way that } \\
\text { they are being } \\
\text { done at the } \\
\text { moment (status } \\
\text { quo scenario); if } \\
\text { the land use } \\
\text { patterns remain } \\
\text { unchanged and the } \\
\text { practice is } \\
\text { continued with to } \\
\text { give preference to } \\
\text { private vehicles as } \\
\text { the transport mode } \\
\text { of choice. }\end{array}$ & $\begin{array}{l}\text { To change things around and } \\
\text { work towards a better transport } \\
\text { scenario, the 5-Year Gauteng } \\
\text { Transport Implementation Plan } \\
\text { (GTIP5) [21] recommends } 13 \\
\text { key, short term initiatives that are } \\
\text { already being implemented by } \\
\text { the Gauteng Department of } \\
\text { Roads and Transport (GDRT) for } \\
\text { completion during the next five } \\
\text { years. } \\
\text { Converting this short-term plan } \\
\text { into a long term planning } \\
\text { framework, the 25-Year } \\
\text { Integrated Transport Master Plan } \\
\text { (ITMP25) [21] recommends eight } \\
\text { significant transport } \\
\text { interventions. This will be } \\
\text { implemented over the next 25 } \\
\text { years, taking into account the } \\
\text { National Development Plan [2] } \\
\text { and its Strategic Investment } \\
\text { Projects (SIPs) [20]; the Gauteng } \\
\text { Vision 2055 and the various } \\
\text { Integrated Transport Plans (ITPs) } \\
\text { developed by local government } \\
\text { (municipalities). How these } \\
\text { proposals could be funded using } \\
\text { various income streams and } \\
\text { funding options. } \\
\text { Institutional arrangements } \\
\text { required to implement and } \\
\text { optimise the GTIP5 [23] and the } \\
\text { proposed ITMP25 [21] } \\
\text { Expected outcomes and benefits } \\
\text { of doing what is proposed. }\end{array}$ & $\begin{array}{l}\text { - Integration of land } \\
\text { use with transport, } \\
\text { as well as } \\
\text { integration of } \\
\text { networks, nodes, } \\
\text { modes and } \\
\text { services; } \\
\text { Applying "smart" } \\
\text { planning principles } \\
\text { by using scarce } \\
\text { resources more } \\
\text { effectively and } \\
\text { through the } \\
\text { application of } \\
\text { suitable } \\
\text { technology; } \\
\text { - Provision for } \\
\text { social inclusion, } \\
\text { with an emphasis } \\
\text { on access to } \\
\text { opportunities and } \\
\text { services; } \\
\text { Beneficiation, } \\
\text { economic growth } \\
\text { and prosperity; } \\
\text { Promotion of a } \\
\text { more sustainable } \\
\text { Gauteng Global } \\
\text { City Region; } \\
\text { Optimising the use } \\
\text { of existing } \\
\text { infrastructure and } \\
\text { future investment. }\end{array}$ \\
\hline
\end{tabular}

Source: own construction from $[18,21,23]$. 
From an intermodal perspective the following principles are applied in the ITMP25 [21]: prioritization of public transport; movement of freight transport from road to rail; containment of urbanization within capacity of transportation systems and infrastructure capacity. The mechanisms to achieve this include reduction of travel demand based on improved intermodal development; promotion of shift in travel patterns; shift in transport modes from private to public transport and application of smart transport technologies inclusive of environmental considerations and application of intelligent transport systems (ITS) to support and enhance travel demand management. Table 4 shows the spatial and transportation interventions included in the ITMP25 [21].

Table 4: Spatial planning and transportation interventions included in ITMP25.

\begin{tabular}{|c|c|}
\hline Spatial planning (land use) interventions & $\begin{array}{c}\text { Transportation planning } \\
\text { interventions }\end{array}$ \\
\hline $\begin{array}{l}\text { Urban form: contain urban sprawl by } \\
\text { limiting future settlements and } \\
\text { economic activities within the urban } \\
\text { edge. } \\
\text { - Densification: promote residential } \\
\text { densification, infill and mixed land use } \\
\text { development within the existing urban } \\
\text { fabric. } \\
\text { - Urban fragmentation: integrate } \\
\text { disadvantaged communities } \\
\text { economically and socially into the } \\
\text { urban system. } \\
\text { Integration: establish nodes with the } \\
\text { improved linkages and connectivity } \\
\text { between areas of economic opportunity } \\
\text { via corridor development. } \\
\text { Intermodal transport: promote viable } \\
\text { public transport and reduce reliance on } \\
\text { private mobility through a strong } \\
\text { emphasis on densification along the } \\
\text { priority public transport corridors and } \\
\text { routes. } \\
\text { Environmental: create a functionally } \\
\text { integrated natural open space system } \\
\text { within the urban core and protected } \\
\text { agricultural and conservation areas. }\end{array}$ & $\begin{array}{l}\text { The } 8 \text { interventions are arranged into the } \\
\text { following four clusters: } \\
\text { - Land Use Development; } \\
\text { - } \quad \text { Strategic Public Transport Network; } \\
\text { Freight Transport; } \\
\text { Road Transport. } \\
\text { Intervention 1: Subsidized } \\
\text { housing provision within the } \\
\text { urban core. } \\
>\text { Intervention 2: Land use } \\
\text { densification. } \\
>\text { Intervention 3: Mainstreaming } \\
\text { non-motorized transport. } \\
>\text { Intervention 4: Reinforcing } \\
\text { passenger rail network as the } \\
\text { backbone of the system. } \\
>\text { Intervention 5: Restructuring and } \\
\text { extending the Integrated Rapid } \\
\text { and Road-based Public Transport } \\
\text { Networks and opportunities for } \\
\text { the Minibus Taxi Industry. } \\
>\text { Intervention 6: Strengthening } \\
\text { freight hubs. } \\
\text { Intervention 7: Travel Demand } \\
\text { Management inclusive of } \\
\text { Travelling Smarter. } \\
\text { Intervention 8: Continued } \\
\text { Sustainable Province-wide } \\
\text { Mobility. }\end{array}$ \\
\hline
\end{tabular}

Source: own construction from [21] and [23]. 
In assessing the feasibility and viability of the principles included in the ITMP25 [21] strategy a 'do-not' scenario for the next 25 years was applied. It includes the GITMP 5 [23] consisting of initiatives for immediate implementation that can be considered as pre-conditions to enhance multimodal transport development. The GTIP5 has identified a number of key initiatives and projects for implementation to achieve immediate impact.

The implementation of the GTIP5 [23] initiatives is focused on infrastructure optimisation, integration of operations and environmental awareness. The assessment of the ITMP25 [21] clearly illustrates that the strategic base for the enhancement and promotion of intermodal transportation systems is sound but fall short in terms of the affordability and accessibility considerations and the development of integrated seamless passenger transportation services.

\section{Interface between planning and development instruments and intermodal transportation development}

From an assessment of the planning and development instruments and its supporting planning actions in enhancing intermodal transport development, the content of Figure 1 illustrates the interface between the strategic and implementation roles of spheres of government in terms of planning, development and implementation for intermodal transportation promotion.

In Figure 1 the complexities of the formulation and coordination of strategic planning and implementation can be deduced. These relationships explain why strategy formulation for the promotion of intermodal transportation is not something that can be viewed to be a top down hierarchical process, timeframe and responsibility only. It responds interactively to system dynamics, management and development needs and realities.

\section{Some lessons learnt for other spatial systems}

- The implementation of intermodal transportation systems is not an event but a process that needs to be planned for within all spheres of government.

- The enabling environment to promote intermodal transportation consists of strategy formulation within a national spatial system as a whole that guides the development of strategies and policies within other spatial systems (refer to Figure 1).

- Intermodal transportation within the regional sphere of government consists of the integration of alternative modes of travel, transport and related spatial planning functions and operational issues.

- The development and promotion of intermodal transport within local spatial systems concerns predominantly intra-traffic and movement patterns. It includes local spatial, transportation and environmental planning and development. The integration of spatial and land use planning within and across local boundaries is thus fundamental. 
- From the research the complex and dynamic nature in planning and implementation of intermodal transportation systems are evident.

- The process of intermodal transportation development is not a hierarchical approach but is driven by 'top-down' and 'bottom-up' activities and interaction inclusive of strategy-, policy and planningformulation supported by implementation and performance system management.

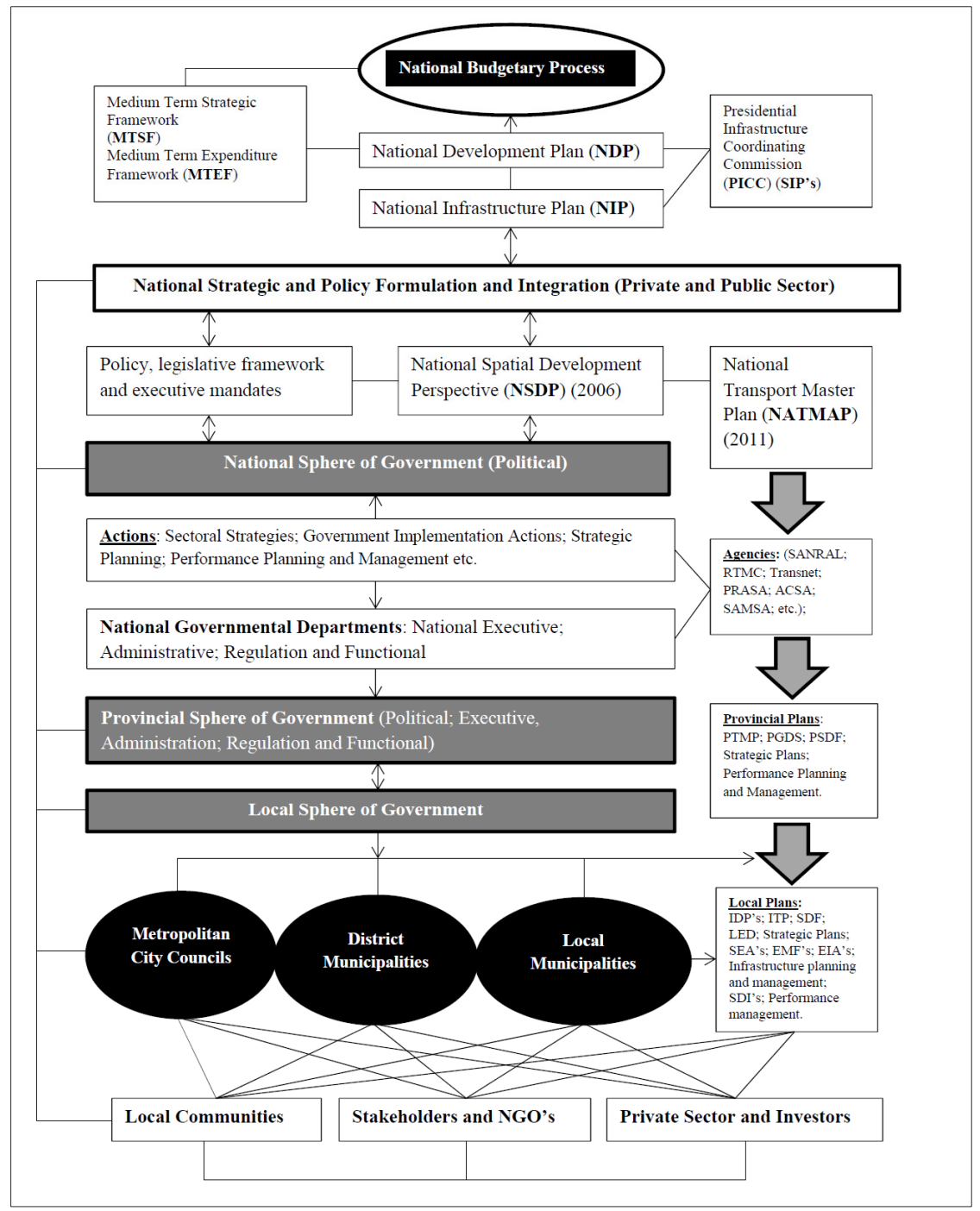

Source: own construction.

Figure 1: Strategic and implementation interface between spheres of government in South Africa in promoting intermodal transportation. 


\section{Conclusions}

From the research the following core conclusions can be deduced:

- The need for the implementation of intermodal and/or multimodal transportation practices within all spatial systems exists.

- $\quad$ The GITMP25 and ITMP5 case study clearly reveals that promotion of intermodal transportation practices and the development of supporting systems need to be addressed from an integrated spatial planning, environmental, economic, social and political perspective.

- All spheres of government need to formulate its strategies, plans and implementation practices by applying top-down and bottom-up linkages through cooperation between professionals within a trans-disciplinary planning, implementation and performance management focus.

- The application of planning and development instruments must be aligned, integrated and reviewed on a regular basis as to ensure sustainable transportation development and delivery within all spatial systems.

- The introduction and promotion of intermodal transportation requires a paradigm shift within all professions involved in transportation and spatial system planning and development.

\section{References}

[1] Republic of South Africa: National Spatial Development Perspective. Pretoria. (2006).

[2] Office of the Presidency: National Planning Commission: National Development Plan 2030. Departmental publication on website: www.thepresidency.gov.za. (2012).

[3] Department of Transport: National Transport Master Plan (NATMAP 2050). Departmental publication on website: www.transport.gov.za. Pretoria. (2011).

[4] US Department Of Transportation: The transportation planning process key issues: A briefing book for transportation decision makers, Officials, and Staff, website: www.planing.dot.gov/documents/briefingbook/bbook. html_(2007).

[5] Hanyane, B.R. 2009. Public transportation system in promoting access and mobility in the Johannesburg central business district, Vol. 44, No 1.1, Department of Public Administration and Management, Pretoria: University of South Africa. (2009).

[6] Pedersen, M.B. 2005. Optimizing models and solution methods for intermodal transportation. http://orbit.dtu.dk/fedora/objects/orbit:86029/ datastreams/file_5579143/content. (2005).

[7] Litman, T: Planning Principles and Practices. Victoria Transport Policy Institiute, Canada. (2011). 
[8] Dressler. S: Strategy, Organisation \& Performance: From Basics to Best Practices. Universal Publishers. Boca Ralton Florida (2004).

[9] Haberberg, A. \& Rieple, A: Strategic Management: Theory and application. Oxford University Press. Pp. 5-92 (2007).

[10] Casey J. Dawkins: Regional Development Theory: Conceptual Foundations, Classic Works, and Recent Developments. Journal of Planning Literature, Vol. 18, No. 2 (November, 2003). Sage Publications (2003).

[11] Nijkamp, P. Infrastructure and regional development: A multidimensional policy analysis. In: Empirical Economics, Vol. 11, Issue 1. pp. 1-21 (1986).

[12] Sussman, J.M. \& Sgouridis, S: Esd Symposium: Regional Strategic Transportation Planning as a CLIOS. Massachusetts Institute of Technology, pp. 2-20 (2004).

[13] CSIR: The Fourth Annual State Logistics Survey for South Africa. http://researchspace.csir.co.za. (2008).

[14] Litman, T: Smart Congestion Relief. Institute for Transportation and Development Policy. Canada (2001).

[15] Asian Development Bank: Changing Course: A New Paradigm for Sustainable Urban Transport. Urban Development Series. (2009).

[16] Litman, T. And Burwell, D: Issues in sustainable transportation. International Journal for Global Environmental Issues, Vol. 6, No. 4, 2006.

[17] Schoeman, C.B: Urban and regional planning and the interface with environmental management and transportation planning. Professorial Inaugural Lecture. North West University, South Africa. Scientific Contributions Series H: Inaugural Address Nr. 238. (2010).

[18] Gauteng Provincial Government: Gauteng Employment Growth and Development Strategy. Johannesburg. (2009).

[19] Office Of The Presidency: National Planning Commission Diagnostic Report. Departmental publication on website: www.thepresidency.gov.za. (2011).

[20] Office Of The Presidency: National Infrastructure Plan. Pretoria. (2012).

[21] Gauteng Provincial Government: Gauteng Integrated Transport Master (Plan 25 Year). (Final Draft) Johannesburg. (2013).

[22] Department Of Transport: NATMAP Phase 4: Consolidated Agenda for Action Report (inclusive of Provincial Reports) (2011).

[23] Gauteng Provincial Government: Gauteng Integrated Transport Master (Plan 5 Year Intervention Strategy-Final Draft). Johannesburg. (2013). 